\title{
EPIDEMIOLOGICAL PROFILE OF ESOPHAGEAL CANCER MORTALITY IN RIO GRANDE DO SUL AND ITS HEALTH REGIONS
}

\author{
Victor Antonio Kuiava1 ${ }^{1}$ Ana Thereza Perin ${ }^{1}$, \\ Richard Ricachenevsky Gurski ${ }^{2,3}$, Carlos Augusto Scussel Madalosso ${ }^{4,5}$, \\ Lisia Hoppe ${ }^{1,5}$, Daniel Navarini ${ }^{1,4,5}$
}

\begin{abstract}
Introduction: Malignant esophageal neoplasia is a rare tumor, but it has high morbidity and mortality. Early diagnosis and intensive treatment associated with surgical approach remains the best treatment for the disease. Its epidemiology is extremely diverse in the world, even in the same country.

Methods: This was a retrospective analysis made from 2000-2015, analyzing the mortality rates of malignant esophageal neoplasia in the state of Rio Grande do Sul (RS) in its 30 Health Regions and in Brazil. The mortality data were collected in the Mortality Information System (SIM) and the population data in the Brazilian Institute of Geography and Statistics (IBGE).
\end{abstract}

Results: The esophageal cancer mortality rate was $8.61(95 \% \mathrm{Cl}, 8.49-8.73)$ per 100,000 inhabitants in RS, while the national rate was $3.66(95 \% \mathrm{Cl}, 3,49-3.82)$, with a significant difference $(p<0.0001)$. The regional distribution was variable, and the West Border region presented the highest rate, 12.91 (95\% Cl, 12.05-13.77). However, even regions with lower mortality presented twice as much deaths than the national rate. Mortality increased with aging, with the oldest age groups ( $\geq 80$ years) presenting $69.62(95 \% \mathrm{Cl}, 64.9-74)$ deaths per 100,000 inhabitants.

Conclusion: Esophageal neoplasia is still a very serious condition in the state of RS, being associated with an almost 3-fold higher mortality rate compared to the national rate. Even within the state different epidemiological patterns are found.

Keywords: Esophageal cancer; epidemiology; mortality

Malignant neoplasm of esophagus is one of the most malignant tumors. It's the sixth cause of death by cancer in the world and the fourth in male mortality in Brazil1,2. It is mainly represented by two histological types, adenocarcinoma, which mainly affects the distal third and gastroesophageal junction, and squamous cell carcinoma, which occurs mainly in the medial third, and these two types represent $95 \%$ of the malignant neoplasms of the $\operatorname{organ}^{3,4}$.

Nowadays, there was a drastic change in the epidemiology of the two histological types. During the last 30 years, especially in the United States and Europe, adenocarcinoma had increased its epidemiology and is currently the main representative of esophageal cancer in the United States, overcoming the squamous cell carcinoma ${ }^{3,5}$.

Both histological types occur more in men, with adenocarcinoma with a ratio of 9:1 in the United States ${ }^{5}$. The most common risk factors for adenocarcinoma are obesity and gastroesophageal reflux disease, both favoring the appearance of Barrett's esophagus, as well as tobacco. For squamous cell carcinoma, alcoholism, tobacco and consumption of hot beverages, such as teas and hot mate, are corroborated by the high incidence in China due to
Clin Biomed Res. 2018;38(3):213-217

1 Faculdade de Medicina, Universidade de Passo Fundo (UPF). Passo Fundo, RS, Brasil.

2 Faculdade de Medicina, Universidade Federal do Rio Grande do Sul. Porto Alegre, RS, Brasil.

3 Departamento de Cirurgia Digestiva, Hospital de Clínicas de Porto Alegre (HCPA). Porto Alegre, RS, Brasil.

4 Clínica Gastrobese. Passo Fundo, RS, Brasil.

5 Departamento de Hepatologia, Hospital São Vicente de Paulo (HSVP). Passo Fundo, RS, Brasil.

Corresponding author: Victor Antonio Kuiava victorkuiava@gmail.com Faculdade de Medicina, Universidade de Passo Fundo (UPF) Rua Teixeira Soares, Centro, 817 99010-080, Passo Fundo, RS, Brasil. 
its culture ${ }^{4,6}$. The age of the patients at the diagnosis of adenocarcinoma is about 53 years, while for the squamous cell carcinoma it is 63 years ${ }^{7}$.

The high aggressiveness is explained by the high rate of metastasis and the late diagnosis, when the lesions are already very advanced ${ }^{4}$. Treatment is done according to stage, but esophagectomy is the gold-standard treatment for curative intent. Stage I patients can be treated for isolated surgical resection of the lesion, but stage II and III patients require neoadjuvant chemotherapy and esophagectomy as treatment. In stage IV, the treatment becomes palliative, with the aid of procedures to treat the dysphagia. At diagnosis, about $60 \%$ of the cases are contraindicated for surgery due to the advanced state of the disease, when it compromises adjacent structures or presents with metastases ${ }^{8,9}$. The overall prognosis of survival in five years is just about $17 \%$, confirming the severity of the neoplasia ${ }^{10}$.

It is known that the epidemiology of esophagus cancer is variable in the world and can have significant differences even within the same country, and Rio Grande do Sul (RS) figures as one of states with the highest mortality rates in Brazil. This is probably due to the culture of drinking hot mate, which is consumed at high temperatures, becoming a risk factor for squamous cell carcinoma. Even within the state the epidemiology is quite variable ${ }^{11}$.

The objective of the present study was to perform an individual evaluation of the mortality of malignant esophageal neoplasia in the 30 Health Regions of Rio Grande do Sul, comparing them with the state and the Brazilian means.

\section{METHODOLOGY}

The present study was an epidemiological, retrospective and descriptive research related to the mortality due to esophageal cancer in the period between 2000 and 2015. The study localization was defined by the state of Rio Grande do Sul and was subdivided in its 30 Health Regions, a division made by the state's Health Secretary. The mortality data of Brazil was also analyzed.

Data about the mortality were collected on the Mortality Information System (SIM-SUS) database, available on the DataSUS website (DATASUS - www.datasus.com.br), and the population numbers were provided by the Brazilian Institute of Geography and Statistics (IBGE - www.ibge.gov.br). The SIM-SUS is a public system that collects and publishes the absolute number of deaths of each disease based on the International Classification of Diseases (ICD). This system covers the data from the whole country.
The population of the study analyzed included patients whose death was attributed to esophageal malignancy in the state of Rio Grande do Sul and in its 30 Health Regions and in Brazil. Data were analyzed and separated according to age group (0-9, 10-19 20-29, 30-39, 40-49, 50-59, 60-69, 70-79 and 80 years or more), sex (female and male), and absolute population of each subcategory. The mortality rates were represented by each 100,000 men or women or both. The calculation was done by multiplying the gross death numbers by 100,000 inhabitants and then dividing the results for the total population of each group analysis. The rates were then adjusted for sex and age.

The statistical analysis was made by the GraphPad Prism program version 6 and with spreadsheets of Microsoft Office Excel 2016 (United States). The statistical comparisons between the years and populations were made by the t-student test for the parametric variables and Mann-Whitney for the non-parametric variables. Significant $p$-values of each analysis were defined as being less than or equal to 0.05 and the confidence interval adopted for the study was $95 \%(95 \% \mathrm{Cl})$.

The results were presented through maps, graphics and tables for better interpretation and exposure of the results. The mortality maps were created on the Adobe Photoshop CC 2015 software using the available map of Health Secretary of Rio Grande do Sul, correlating with the data provided by the SUS mortality system. Available from: http://www.saude. rs.gov.br/regioes-de-saude [cited 2018 May 6], and the graphics on GraphPad Prism version 6.

\section{RESULTS}

A total of 14,927 deaths from malignant esophageal neoplasia occurred in RS from 2000 to 2015, representing a mortality rate of $8.61(95 \% \mathrm{Cl}, 8.49-8.73)$ deaths per 100,000 inhabitants in the state. Brazil had 111,106 deaths in the same period and its average mortality rate was $3.66(95 \% \mathrm{Cl}, 3.49-3.82)$ per 100,000 inhabitants. The difference between the two rates was significant $(p<0.0001)$, see figure $1 b$.

There is a clear predominance of men over women with a $3: 1$ ratio. The mean age of men was $64.6(95 \% \mathrm{Cl}, 64.1-65)$ years old and $70.2(95 \% \mathrm{Cl}, 69.7-70.75)$ for women in RS. The mortality rates adjusted by sex were 13.10 and 4.28 for every 100,000 men and women, respectively.

Mortality rates were progressively higher for older age groups, with the peak found for both sexes at $\geq 80$ years, with $117.99(95 \% \mathrm{Cl}, 109-126.6)$ 
deaths per 100,000 men and $44.93(95 \% \mathrm{Cl}, 41.3-48.7)$ for women. Extremely rare cases occurred under the age of 40 , see figure 1 a.

It was observed that there were significant reductions $(p<0.05)$ in mortality rates for some age groups analyzed during the years 2000 to 2015 , male populations between 50-59, 60-69, 70-79 had $37,29,27$ percent drop, respectively. While in the female group only the age group above eighty years showed a fall of 68 percent.
When analyzed for the geographical differences of the RS state (Figure 2), there was a great disparity in mortality rates. The western part of the state had the highest mortality rates of the neoplasia. The Health Region that had the highest mortality rate was the West Border region, with 12,91/100,000 deaths (95\% Cl: 12.05-13.77), while the lowest rates were found in the Capital/Gravataí region - 6,54/100,000 (95\% Cl: 6.26-6.82). All regions had at least twice as many deaths as the national average, which was 3.66 (95\% Cl, 3.49-3.82) per 100,000.

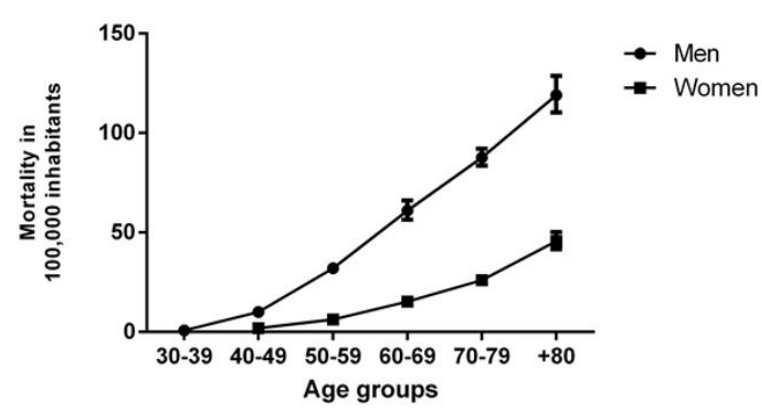

(a)

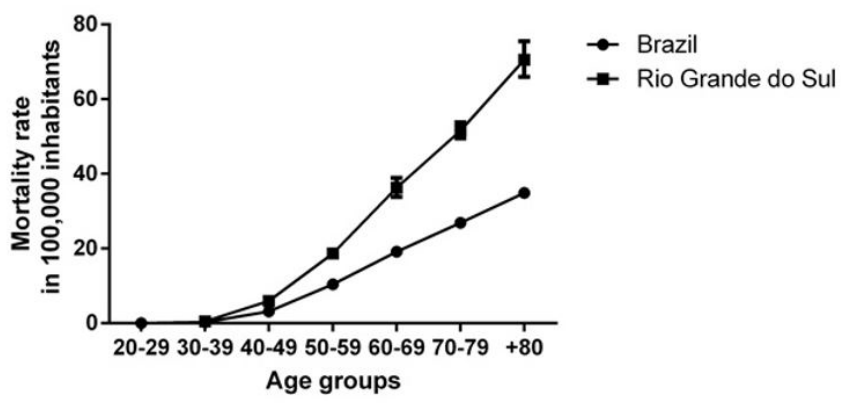

(b)

Figure 1: Differences on the mortality rates of esophageal cancer per 100,000 inhabitants comparing men and women (a) and Brazil and Rio Grande do Sul (b).

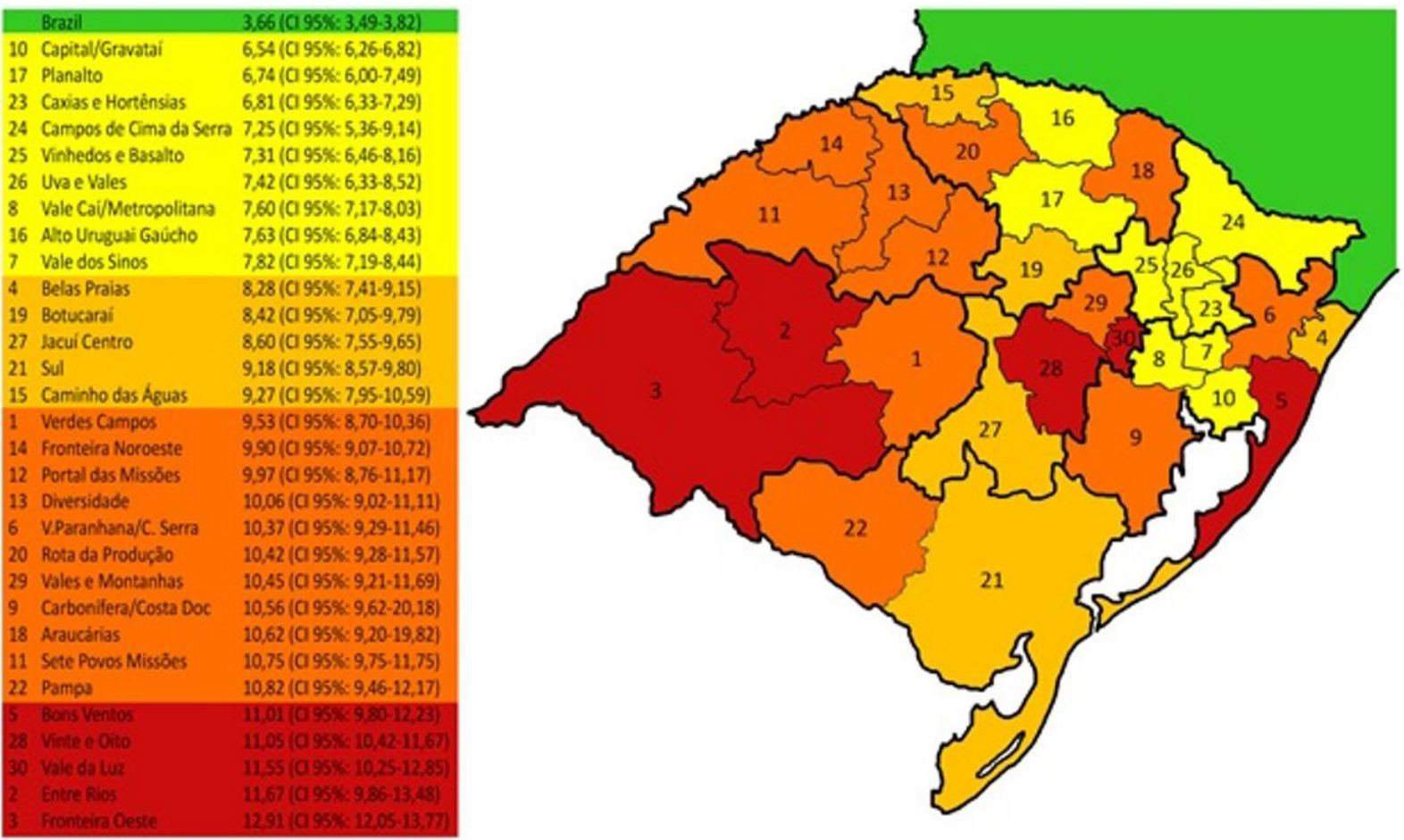

Figure 2: Mortality rates of esophageal cancer in the 30 Health Regions of Rio Grande do Sul from 2000 to 2015. 


\section{DISCUSSION}

The results show that Rio Grande do Sul is an endemic region for malignant esophageal neoplasia, since its mortality is almost three times higher than the national level. In addition, the state presents a different national and international epidemiological pattern. Analysis of the worldwide literature indicates an increase in the number of cases and mortality rates of esophageal malignancy mainly in America and Europe, most of all due to an increase in risk factors for esophageal adenocarcinoma, such as obesity, GERD and Barrett's esophagus ${ }^{5-7}$. In a national analysis, RS shows rates three times higher than Brazil, and this trend has remained over the years.

This fact can be explained by different cultural patterns that the region presents. The practice of drinking hot mate is presented as one of the risk factors, increasing by 160 percent the incidence in a meta-analysis ${ }^{12}$. The consumption and preparation of the herb may also be responsible. The consumption of hot drinks $(>60 \circ C)$ is a factor of esophageal mucosa lesion and oncogenesis, and in addition, due to the fact that the herb preparation underwent a drying process on the fire, polycyclic aromatic hydrocarbons carcinogens also present in the cigarette - was found in the urine of individuals who regularly consume the drink ${ }^{11,13,14}$.

It is noticed that the epidemiological pattern of this neoplasia is changing over time in the state. A retrospective study with a similar methodology, analyzing the years 1979-1989, showed that state rates had increased during that period ${ }^{15}$. However, this study demonstrates a significant decrease for older age groups, possibly due to declines in risk factors, such as smoking and alcoholism, associated with better treatments of the disease, such as the use of neoadjuvant therapies ${ }^{16}$.

In Asia, there is an endemic region that extends from Iran, China and Russia called "Asian Esophageal Cancer Belt" in which the highest rates of incidence and mortality of esophageal squamous cell carcinoma are found worldwide. In this region, the incidence reaches 100 cases per 100,000 inhabitants. This numbers can be explained by their diet costumes, like the consumption of hot drinks and pickled vegetables. Because of the high incidence, programs of screening were implanted in these countries for an early detection of esophageal cancer $^{1,17}$. The mortality rate in China in 2012 was 15.58 deaths for 100,000 inhabitants ${ }^{18}$.

Malignant neoplasm of the esophagus has a high mortality rate, reaching only $20 \%$ of survival in 5 years ${ }^{10,19}$, and $60 \%$ of the patients have an unresectable disease at the time of diagnosis ${ }^{9}$. Considering this lethality, mortality analysis data can infer epidemiological patterns, since diagnostic and mortality rates tend to be similar.

According to the National Cancer Institute (INCA) ${ }^{20}$, the different treatments depend on the stage of the disease. For early tumors, the curative treatment can be done by endoscopic resection, but it is very rare because of the late diagnosis. Intermediate levels of the disease are treated with esophagectomy surgery and for advanced stages the treatment is only palliative with chemotherapy, radiotherapy, endoscopic dilatations or esophageal prostheses in order to relieve some consequences like dysphagia and poor nutrition. Rohde and Osvaldt ${ }^{9}$, authors of a book on digestive surgery based on the experience of one of the biggest hospitals in Rio Grande do Sul, defines the treatment for each TNM standard: local resection for stage I patients, esophagectomy and chemotherapy for stage II and III, and palliative for stage IV patients.

This study has some limitations concerning the database that provided the mortality information. The SIM system provides secondary data that does not allow the researcher to control possible taping and registry mistakes. Besides, there can also be under notification on the deaths that occurred during the period. However, this database provides official information and its filing is mandatory in the whole country, thus the results can be trusted.

As a conclusion, esophageal cancer in Rio Grande do Sul remains extremely worrying. With all Health Regions presenting higher means than the Brazilian average, and a mean mortality rate in the state almost three times higher than the national rate, it is clear that the situation is alarming, especially on the western regions, where the numbers show an extremely high mortality.

\section{Conflicts of Interest}

The authors declare no conflicts of interest.

\section{REFERENCES}

1. Liang $\mathrm{H}$, Fan JH, Qiao $\mathrm{YL}$. Epidemiology, etiology, and prevention of esophageal squamous cell carcinoma in China. Cancer Biol Med. 2017;14(1):33-41. http:// dx.doi.org/10.20892/j.issn.20953941.2016.0093. PMid:28443201.

2. Instituto Nacional do Câncer (INCA). Atlas On-line de Mortalidade; c2018. [cited 2018 May 6]. Available from: www.mortalidade.inca.gov.br/
3. UpToDate. Waltham: Clinical manifestations, diagnosis, and staging of esophageal cancer; c2018. [cited 2018 Mar16]; Available from: https:// www.uptodate.com/

4. UpToDate. Waltham: Epidemiology and pathobiology of esophageal cancer. [cited 2018 Mar 16]. Available from: https://www.uptodate.com/
5. Coleman HG, Xie SH, Lagergren J. The Epidemiology of Esophageal Adenocarcinoma. Gastroenterology. 2018;154(2):390-405. http://dx.doi. org/10.1053/j.gastro.2017.07.046. PMid:28780073.

6. Henry MACA, Lerco MM, Ribeiro PW, Rodrigues MA. Epidemiological features of esophageal cancer. Squamous cell carcinoma versus adenocarcinoma. Acta 
Cir Bras. 2014;29(6):38993. http://dx.doi.org/10.1590/ S0102-86502014000600007. PMid:24919048.

7. Eslick GD. Epidemiology of Esophageal Cancer. Gastroenterol Clin North Am. 2009;38(1):xiiixiv. http://dx.doi.org/10.1016/j. gtc.2009.01.013.

8. Alsop BR, Sharma P. Esophageal Cancer. Gastroenterol Clin North Am. 2016;45(3):399-412. http:// dx.doi.org/10.1016/j.gtc.2016.04.001. PMid:27546839.

9. Rohde L, Osvaldt AB. Rotinas em Cirurgia Digestiva. 3rd ed. Porto Alegre: Artmed; 2018. 217-236 p.

10. Tustumi F, Mayumi C, Kimura S, Takeda FR, Uema RH, Antônio $\mathrm{R}$, et al. Fatores Prognósticos e Análise de Sobrevida no Carcinoma Esofágico. Arq Bras Cir Dig. 2016;29(3):138-41. http://dx.doi.org/10.1590/01026720201600030003 . PMid:27759773.

11. Barros SGS, Ghisolfi ES, Luz LP, Barlem GG, Vidal RM, Wolff $\mathrm{FH}$, et al. Mate (chimarrão) é consumido em alta temperatura por população sob risco para o carcinoma epidermóide de esôfago. Arq Gastroenterol. 2000;37(1):25-
30. http://dx.doi.org/10.1590/ S0004-28032000000100006. PMid:10962624.

12. Andrici J, Eslick GD. Maté consumption and the risk of esophageal squamous cell carcinoma: A meta-analysis. Dis Esophagus. 2013;26(8):807-16. http://dx.doi.org/10.1111/j.14422050.2012.01393.x. PMid:22891687.

13. Lubin JH, De Stefani E, Abnet CC, Acosta G, Boffetta P, Victora C, et al. Maté drinking and esophageal squamous cell carcinoma in South America: pooled results from two large multi-center case control studies. Cancer Epidemiol Biomarkers Prev. 2014;23(1):107-16. http://dx.doi. org/10.1158/1055-9965.EPI-13-0796. PMid:24130226.

14. Golozar A, Fagundes RB, Etemadi A, Schantz MM, Kamangar F, Abnet $\mathrm{CC}$, et al. Significant variation in the concentration of carcinogenic polycyclic aromatic hydrocarbons in yerba maté samples by brand, batch and processing method. Environ Sci Technol. 2012;46(24):13488-93. http://dx.doi.org/10.1021/es303494s. PMid:23101992.

15. Prolla JC, Dietz J, Costa LA. Diferenças geográficas na mortalidade por câncer de esôfago no Rio Grande do Sul. Rev Assoc Med Bras. 1993;39(4):217-20. PMid:8162085.
16. Tercioti V JR, Lopes LR, Coelho Neto JS, Andreollo NA. Aspectos atuais da terapêutica Neo-Adjuvante no carcinoma epidermóide do esôfago: revisão da literatura. $A B C D$ Arq Bras Cir Dig. 2009;22(1):33-40. http://dx.doi.org/10.1590/S010267202009000100008.

17. Kamangar F, Malekzadeh R, Dawsey SM, Saidi F. Esophageal cancer in Northeastern Iran: A review. Arch Iran Med. 2007;10(1):70-82. PMid:17198458.

18. Chen W, Zheng R, Zuo T, Zeng $\mathrm{H}$, Zhang S, He J. National cancer incidence and mortality in China, 2012. Chin J Cancer Res. 2016;28(1):1-11. PMid:27041922.

19. Napier KJ, Scheerer M, Misra S. Esophageal cancer: A Review of epidemiology, pathogenesis, staging workup and treatment modalities. World J Gastrointest Oncol. 2014;6(5):112-20. http:// dx.doi.org/10.4251/wjgo.v6.i5.112. PMid:24834141.

20. Instituto Nacional do Câncer (INCA). Esôfago - tratamento. c2018. [cited 2018 May 6]. Available from: http://www2.inca.gov.br/wps/wcm/ connect/tiposdecancer/site/home/ esofago/tratamento

Received: Jun 26, 2018 Accepted: Sept 27, 2018 